J. Linguistics 58 (2022), 1-35. C The Author(s), 2021.

Published by Cambridge University Press. This is an Open Access article, distributed under the terms of the Creative Commons Attribution-NonCommercial-NoDerivatives licence (http://creativecommons.org/ licenses/by-nc-nd/4.0/), which permits non-commercial re-use, distribution, and reproduction in any medium, provided the original work is unaltered and is properly cited. The written permission of Cambridge University Press must be obtained for commercial re-use or in order to create a derivative work. doi: $10.1017 /$ S0022226721000116

\title{
Regular and compositional aspects of NPN constructions $^{1}$
}

\author{
TORODD KINN (D) \\ University of Bergen
}

(Received 26 February 2020; revised 15 December 2020)

The article proposes a novel analysis of NPN constructions, exemplified by English expressions like back to back and year after year. An NPN is typically composed of two identical bare singular count nouns with a preposition between them. Previous research tends to treat NPNs as highly idiosyncratic. While acknowledging some idiosyncrasies, the present contribution shows that NPNs exhibit a considerable degree of regularity and compositionality. A widespread view that bare singulars normally do not function as arguments is shown to rest on weak foundations. As a consequence, the present approach is able to show that NPNs are, at the core, NPs with PP modifiers. Nominal NPNs have this basic structure, while adverbial NPNs involve an extra layer of semantics and are exocentric constructions. A distinction between nominal types and instances is employed to account for the semantics of bare singulars. NPNs exhibit two kinds of emergent meanings, leading to chain NPNs and twin NPNs. The different semantic structures of these NPN subtypes explain why some NPNs can have nominal in addition to adverbial functions. The data comes mostly from Norwegian. Details differ between languages, but central parts of the analyses can be assumed to hold for other languages as well.

KEYWORDS: adverbial NPs, bare singulars, instances, NPNs, prepositions, types

\section{INTRODUCTION}

Expressions like English back to back and year after year are found in several European languages. The examples in (1)-(2) show Norwegian equivalents:

[1] Thanks to the audiences at Constructions in the Nordics 1 and at Møte om norsk språk 18 for valuable suggestions. Thanks to Sandra Halverson, Porsteinn Indriðason, Benedicte M. Irgens, Gabriele Knappe, and Harry Solvang for their help. Thanks to the three referees of Journal of Linguistics, whose criticisms and suggestions have helped me to improve the text.

Abbreviations in glosses follow the Leipzig Glossing Rules. LBK = Lexicographic Corpus of Norwegian Bokmål, see Knudsen \& Fjeld (2013) and https://www.hf.uio.no/iln/om/organisasjon/ tekstlab/prosjekter/lbk. 
(1) slik at vi faktisk står rygg mot rygg so that we actually stand back against back 'so that we're actually (standing) back to back'

(2) Siden har år etter år gått uten noen bedring since has year after year gone without any improvement 'Since then, year after year has gone by without any improvement.'

Expressions like rygg mot rygg and år etter år will be referred to as 'NPN constructions', or just 'NPNs'. An NPN consists of two identical singular count nouns (N1 and N2) with a preposition (P) between them. ${ }^{2}$ (In languages with case marking on nouns, the nouns may have different cases.) An NPN typically consists of nothing more. The nouns are bare singular count nouns - 'bare singulars' for short. The notion of 'bare singular' is compatible with the presence of modifiers, but NPNs typically have none (except that the PN sequence will be analysed here as a modifier of N1). In English, modifying adjectives are found, as in (rainy) day after rainy day, for example, which is very uncommon in Norwegian. We will look at two other modifier types. The first type is PPs in NPNs with measure nouns, headed by med 'with' or $a v$ 'of' whose complement designates the measured mass, as in $(3):^{3}$

(3) Erla destillerer liter på liter med sprit

Erla distils litre on litre with spirits

'Erla distils litre upon litre of spirits.'

Such PPs are constituents of the NP headed by N2, and will therefore be called internal modifiers. Semantically, they modify both nouns, a property that makes these NPNs resemble coordinate structures (see Sections 2.2 and 4.4 below).

A different kind of PP modifier is illustrated in (4)

(4) Ansikt til ansikt med Vespasian og Titus sa han:... (LBK)

face to face with Vespasian and Titus said he

'(Standing) Face to face with Vespasian and Titus, he said: ...'

:The phrase headed by med modifies not the nouns (ansikt med Vespasian og Titus 'face with Vespasian and Titus' makes no sense), but the whole NPN meaning. Such modifiers will be called external, and I discuss them briefly in Section 5.2 below.

Identical nouns (except for case) are by definition a necessary property of NPNs. ${ }^{4}$ Non-NPN variants with different nouns are often hardly acceptable, such as *?day

[2] A fairly common variant involves three (or more) identical nouns, e.g. day after day after day. These may be considered NPNs, but they are not discussed further here.

[3] Med and $a v$ are the prepositions that appear in Norwegian pseudopartitive constructions, corresponding to English of; see Kinn (2001).

[4] Various NPN-like expressions may be found. Norwegian examples are én etter én [one after one] 'one by one' (repeated quantifier), blått $i$ blått [blue in blue] 'lots of blue' (repeated neuter adjective), millioner på millioner 'millions upon millions' (repeated plural measure noun), luft bak 
after night as a variant of day after day. ${ }^{5}$ However, an NPN like hand in hand may be changed into non-NPN paw in hand, for example. Some such non-NPNs are unremarkable; compare man against man and man against animal. The difference in acceptability between *?day after night and paw in hand will be shown to follow from semantic structure and to correlate with differences in syntactic function.

NPNs are typically used in various adverbial functions, like rygg mot rygg in (1). ${ }^{6}$ But in several Germanic languages, at least, certain kinds of NPNs are also used in nominal (argument) functions, like the subject in (2) and the object in (3). Kinn (2021a) finds that adverbial and other modifying functions (e.g. modifiers of nouns) account for about $80 \%$ of the NPN tokens in Norwegian Bokmål, while $20 \%$ are nominal. $^{7}$

In parts of the research literature, NPNs are regarded as highly idiosyncratic and problematic to analyse. This has to do with the untypical use of bare singulars, the identity of the nouns, and the relation between two singular nouns and potentially many instances of the nominal type (e.g. several days in the case of day after day).

The most influential contribution to the research on NPNs has so far been Jackendoff (2008). Jackendoff discusses a number of properties of English NPNs and argues that they constitute an entrenched structure violating standard principles of phrase structure - a 'syntactic nut' in the sense of Culicover (1999).

The present contribution aims to show that NPNs are more regular than typically assumed, inheriting a number of formal and semantic properties from more schematic constructions. They also have clear compositional properties, central parts of their meanings being predictable from the components and their manner of combination. Most properties of NPNs are properties of bare singulars, prepositions, prepositional phrases, and noun phrases in general.

However, NPNs do have idiosyncratic properties, especially adverbial use of NPs (exocentricity), emergent constructional meanings, and lexicalization of some expressions. Without irregular and noncompositional properties, NPNs would not have been so easily identifiable as a construction worthy of special attention. It is the aim of the present article to highlight regular and compositional aspects, and to contribute to a better understanding of certain idiosyncrasies.

The evidence here is mostly from Norwegian, but it is compared to English examples. Some Icelandic data is adduced because that language as opposed to Norwegian has case-inflected nouns. The present study draws on the corpus study of Kinn (2021a). That work on Bokmål Norwegian NPNs builds on materials of 9,241 NPN tokens from the Lexicographic Corpus of Norwegian Bokmål (Knudsen

luft 'air behind air' (repeated mass noun), etc. Thus, the central NPNs are part of a wider constructional network.

[5] Such expressions appear to be very unusual, but I cannot claim, of course, that they are never produced.

[6] Adverbial NPNs, while semantically modifying expressions, may still be valency bound, as in $W e$ live side by side.

[7] Some NPNs appear in expressions like case-by-case approach, as prenominal modifiers or first parts of compounds. 
\& Fjeld 2013). ${ }^{8}$ Most Norwegian NPNs involve one of eight prepositions (seven of which are discussed here), ${ }^{9}$ but the corpus study also documents NPNs with several less frequent prepositions.

Borthen's (2003) work on bare singulars is a central source of inspiration. My theoretical approach draws most clearly on that of Cognitive Grammar (Langacker 1987 , 1991) but is broadly compatible with constructional approaches to grammar in general (see the contributions in Hoffmann \& Trousdale (2013). ${ }^{10}$ A semantic analysis in terms of construal (rather than truth conditions) is at the core of the approach. This is an important point, and I emphasize that terms like ASYMMETRIC, RECIPROCAL, and TRANSITIVE refer to conceptual semantics here and must be understood in that context. Asymmetry is by definition a property of prepositional relations, relating a trajector and a landmark. A relation $\mathrm{R}$ is reciprocal if $R(a, b)$ means also that $R(b, a)$. A relation $\mathrm{R}$ is transitive if $R(a, b) \& R(b, c)$ means also that $R(a, c)$.

Section 2 reviews the research on NPNs and expands on the objectives of the present work. An important question for the analysis of NPNs has to do with the properties of bare singulars, and this is addressed in Section 3. On that background, Sections 4 and 5 deal with the internal semantic structures and external connections of NPNs. Section 6 concludes the article.

\section{Research baCKGRound AND PRESEnt obJectives}

Studies that (exclusively or partly) deal with properties of NPNs (and/or PNPNs) ${ }^{11}$ include Pi (1995), Postma (1995), Travis (2001, 2003), Lindquist \& Levin (2003), Matsuyama (2004), Beck \& von Stechow (2005, 2007), Poss/Poß (2007, 2010), Jackendoff (2008), Boberg (2009), König \& Moyse-Faurie (2009), Roch, Keßelmeier \& Müller (2010), Müller (2011), Pskit (2012, 2015, 2017), Haïk (2013, 2018), Zwarts (2013), Magri, Purnelle \& Legallois (2016), Ziem (2018), Beck (2021), and

[8] Before syntactic analysis, the materials included more than 14,000 potential NPNs. Some were NPN sequences that did not form a constituent (see Section 3.2 for examples). Many examples involved PNPNs rather than NPNs. An English PNPN example is (the journey) from town to town. PNPNs resemble NPNs but are clearly distinct from them. In NPNs, the PN sequence is a PP modifying N1. In PNPNs, the two PN sequences are juxtaposed PPs forming a construction together. The same general construction is found in (the journey) from London to Paris. The PP to Paris is not a modifier of London (London does not move to Paris); from London and to Paris are juxtaposed. In NPNs, the preposition relates N1 and N2, while the second preposition of PNPNs does not. Both prepositions of PNPNs relate the immediately following noun to a constituent outside of the PNPN. In (the journey) from town to town, the PP to town does not describe a town but the journey.

[9] The eighth is om 'about, around', which is almost only used in the lexicalized NPN side om side 'side by side'.

[10] It has been questioned whether my purpose of identifying compositionality is in line with Cognitive Grammar. Certainly, it is not an assumption of Cognitive Grammar that all constructions are compositional; some exhibit a high degree of compositionality while others do not. Finding systematicity is as much an objective of Cognitive Grammar as of other linguistic schools, but regularity and compositionality are not taken for granted.

[11] See footnote 8 above. 
Kinn (2021a, b). In the following subsections, some aspects of this research literature will be reviewed and discussed in order to prepare the ground for a new analysis.

These works look at (P)NPNs in English, Dutch, German, French, Spanish, and Polish - three branches of the Indo-European languages. I have no information about NPNs in other languages. ${ }^{12}$ It is generally difficult to find treatments of these constructions, even for the well-described Scandinavian languages. For Norwegian, all I have found is a brief paragraph in Faarlund, Lie \& Vannebo (1997: 456) and dictionary entries.

\subsection{Bare singulars and NPN structure and constituent-hood}

Some researchers have proposed fairly regular phrase structure analyses of NPNs. Thus, Travis $(2001,2003)$ proposes analyses in terms of X-bar theory, and Haik (2013) uses similar phrase structures - although she takes the bareness of the nouns to be evidence that NPNs are morphological rather than syntactic structures. Poß (2010: 50) presents an analysis in Sign-Based Construction Grammar where NPNs are a kind of NPs with ternary branching and the PN sequence does not form a constituent.

Jackendoff (2008) does not state it explicitly, but an important reason for him to regard NPNs as idiosyncratic appears to be the use of bare singulars. An idea that is prevalent in some approaches to syntax (dating back at least to Longobardi 1994) is that bare singulars are normally not able to function as arguments (in languages that have articles). ${ }^{13}$ This accounts, for example, for the observation that sentences like Anne threw the ball and Anne threw a ball are grammatical, but *Anne threw ball is not (in most contexts).

Jackendoff (2008) seems to assume that the restriction on bare singulars holds for NPNs. This has far-reaching implications for his understanding of the constructions. First, it is unclear whether he regards N2 as the complement of P: 'What follows the preposition is not a normal prepositional object, since ... it cannot have a determiner' (Jackendoff 2008: 19). Jackendoff does not once refer to the PN sequence as a PP or to $\mathrm{N} 2$ as the object/complement of P. In his constructional representation of NPNs (on page 26), no PP is identified in syntax. P and N2 are shown as sister constituents of an NP (headed by P); see further Section 2.2 below. While Jackendoff does not explicitly deny that N2 may be some kind of complement of $\mathrm{P}$, there is also no clear indication that he adopts such a view.

Second, N1 is seen as unable to head arguments (e.g. in NPNs such as those in (2) and (3) above), hence is not the head of NPN. When considering and rejecting

[12] Matsuyama (2004) discusses a similar construction in Japanese, $N$ ni tugu $N$, but this involves a verb (tugu), 'N which follows (after) N'.

[13] The term ARGUMENT is used here as in Cognitive Grammar (Langacker 1987: 309): A typical argument in a construction is a non-head whose profile is nominal (a 'thing') and elaborates (fills an empty slot in) the profile of the head of the construction. This mainly means subjects and objects of verbs and complements of prepositions. 
the possibility that a nominal NPN is headed by N1, Jackendoff (2008: 20-21) says that 'it is quite a peculiar NP: notice again that the noun must lack a determiner ... I would suggest that if there is any head at all in $N$ after $N$, it is the preposition ... it is an NP headed by P'.

Research on several article languages, including English (e.g. Stvan 2007) and Norwegian (Borthen 2003), has documented several constructions where bare singulars do occur in argument positions. Bare singulars tend to have different referential properties from count singulars with indefinite articles (e.g. ball vs. $a$ ball), and the conditions for their use are partly semantic rather than syntactic (see Section 3) and certainly in part language specific.

It will be argued in Section 3 that the basic structure of NPN has N1 as the head of an NP. The sequence of P and N2 is a PP modifying N1. N2 is the head of an NP complement in that PP. Adverbial NPNs have an extra semantic layer turning the basic NPN structure into an exocentric construction (see further Section 5.2 below).

An NPN is one constituent in an embedding construction, often verb-headed (verb phrase, clause, or sentence). This can be demonstrated with reliable tests for constituent-hood, viz., substitution and topicalization (see Müller 2011 on German NPNs). Adverbial NPNs like rygg mot rygg 'back to back' in (1) above can be replaced with a single adverb like slik 'thus', and nominal NPNs like år etter år 'year after year' in (2) above can be replaced with a single pronoun like de 'they'. Further, since Norwegian V2 syntax normally allows only one topicalized constituent in front of the finite verb, (5) and (6), which are reformulations of (1) and (2), also demonstrate the constituent-hood of the NPNs:

(5) Rygg mot rygg står vi faktisk.

back against back stand we actually

'We are actually (standing) back to back.'

(6) ̊̊r etter år har siden gått.

year after year has since gone

'Year after year has gone by since then.'

These properties argue against an analysis of NPNs as small clauses (as proposed by Haïk (2013) for some NPNs, see Section 2.2). Whether one adopts the concept of small clauses or not (see Saurenbach 2008 for discussion), putative small clauses with PPs (e.g. him beneath contempt in English Mary considers him beneath contempt) can neither be replaced with one pro-word nor be topicalized. Thus, while NPNs can be shown with basic syntactic tests to be constituents, the opposite holds for small clauses.

The PP of NPNs bears a predicate relation to N1. This is similar to the relation of the PP to the preceding nominal constituent in a small clause (e.g. of beneath contempt to him in the example). However, this similarity is not an argument for small clause status, because such a predicate relation is a property of PP modifiers in NPs in general, for example, the books on the table, a woman with a hat, etc. 


\subsection{Number properties of NPNs and the role of the preposition}

NPNs exhibit complex number properties. In hand in hand, the two singular nouns may correspond to two or more actual hands (The couple (s) walked hand in hand). In an NPN like guest after guest, the nouns presumably always correspond to at least three guests. Such NPNs have a plural-like semantics. Nominally functioning NPNs are singular in terms of clause-internal agreement properties in English: Guest after guest was leaving the party (see also Section 3.3 on Icelandic). But they may be antecedents of plural pronouns, as in the possible continuation They didn't like the music.

The plural-like meaning of NPNs often goes together with a plurality of events; the guest example means something like 'One guest left the party, then another guest left, then another, etc.' These phenomena are not in focus here, but see Beck \& von Stechow (2007), Zwarts (2013), and Beck (2021).

Several researchers (e.g. Postma 1995; Travis 2001, 2003; (partly) Jackendoff 2008; Müller 2011; Haïk 2013) have assumed that NPNs involve reduplication, where N1 is a copy of N2 in syntax. This implies that there is in a sense only one singular noun in syntax, creating a mismatch with semantics since all NPNs involve at least two instances of one nominal type.

In Travis (2001, 2003), P is analysed as a quantifier with reduplicative power; it takes N2 as its complement and makes a copy (N1) which becomes its specifier. This quantifier is the head of the NPN and is responsible for the reduplicated noun corresponding to two or more instances of the nominal type.

Haik (2013) distinguishes between two kinds of English NPNs. Those that cannot function nominally are analysed as lexical small clauses (recall Section 2.1 above) headed by $\mathrm{P}$, regarded as a preposition. However, a preposition normally relates the meaning of the complement (landmark) to a meaning element (trajector) expressed outside of the PP. That appears not to be the case on Haïk's analysis.

NPNs which can function nominally (in English: those with after or (up)on) are analysed by Haïk as lexical coordinate structures headed by a reduplicated noun. $\mathrm{P}$ is regarded as a coordinator and causes the one singular noun in syntax to correspond to a plurality in semantics. One reason for this analysis is that these NPNs behave in some ways like coordinate constructions. For instance, in an expression like layer upon layer of clothes, the PP of clothes connects equally to both nouns (at least in semantics). As is known, this is a characteristic of coordinated constituents (a figurine and a bracelet of gold - both the figurine and the bracelet may be understood to be golden) and not of structures where a PP modifies a noun (a figurine [with a bracelet [of gold]] - only the bracelet is said to be golden). ${ }^{14}$

In Jackendoff (2008), it is unclear whether N2 is seen as the complement of P (see Section 2.1). Further, on page 26, he preferentially regards N1 as a reduplicated

[14] I refrain from bracketing the coordinate expression, since its hierarchical structure is in dispute and not essential here. 
copy of N2. The one-to-many relationship between noun and referents is stipulated there as follows: ${ }^{15}$

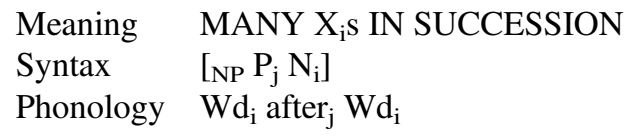

As indicated by the subscript letters in this representation, one syntactic nominal entity corresponds to many semantic ones and two phonological ones $(\mathrm{Wd}=$ word $)$. The $\mathrm{P}$ in syntax corresponds to nothing in semantics. Normally, a preposition takes a complement in syntax and relates two participants in semantics. Such a valency is not apparent in Jackendoff's representation.

The prepositions of NPNs are formally identical to prepositions found elsewhere, and their meanings in NPNs are found also in other constructions (see Section 4 below). Consider day after day: Part of the meaning is that one day is after another day. Similarly, hand in hand is used about situations where one hand is in contact with and partly enclosed in another hand (see Poß 2010: 75). In short, the preposition semantically connects $\mathrm{N} 1$ and N2 in the usual manner of a preposition.

\subsection{NPN subtypes and external connections}

NPNs can be subclassified in different ways based on syntactic or semantic properties. The relations between internal NPN semantics and adverbial vs. nominal function have thus far scarcely been explored in the literature, but such relations will be shown to be quite central to an understanding of the constructions.

Jackendoff (2008) notes that some subtypes of English NPNs ( $N$ after $N$ and $N$ (up)on $N$ ) can function nominally, while others cannot. This appears to underlie Haïk's (2013) distinction between lexical coordinate NPNs (with after or (up)on) and lexical small-clause NPNs (the rest). Primarily interested in NPNs with reciprocal meanings such as hand in hand and face to face, König \& MoyseFaurie (2009) distinguish between those and others in English. Nonreciprocal NPNs include at least the potentially nominal $N$ after $N$ and $N($ up $)$ on $N$. For König \& Moyse-Faurie, the dichotomy reflects their interest in reciprocity, but it is important in the subclassification of NPNs. (See also Beck \& von Stechow (2005, 2007).)

Jackendoff (2008: 17) presents a subclassification of English NPNs in the form of an inheritance hierarchy based on the individual prepositions involved. Apart from a ragbag class, he has five major subtypes, each coupled with one preposition and one or more constructional meanings: $N$ by $N$ (succession), $N$ for $N$ (matching/exchange), $N$ after $N$ (succession), $N$ (up)on $N$ (succession; large quantity), and $N$ to $N$

[15] He also presents an analysis without reduplication where there are two nouns, and he does acknowledge problems with reduplication in case-marking languages where the nouns may have different cases (see also Pskit 2015 on Polish NPNs, and see Section 3.3 below on Icelandic). 
(juxtaposition; succession; transition; comparison). He concludes (on page 16) that NPNs have no predictable common meaning. He does recognize (page 18) pairing (related to reciprocity and twin NPNs, see Sections 4.5 and 4.6 below) and multiplicity, involved in succession (related to transitivity and chain NPNs, see Sections 4.3 and 4.4 below), but he does not complete any higher-level grouping on this basis, nor does he tie semantics to syntax. A similar classification to Jackendoff's is found in Poß (2010: 50), and Roch et al. (2010) build explicitly on Jackendoff (2008). To sum up, Jackendoff's subclassification is of a splitting kind, while certain other researchers propose larger subtypes.

Nominal NPNs are assigned a semantic role by the governing verb or preposition, but (case-less) adverbial NPNs have no overt expression of the semantic role of the NPN in an embedding construction (usually verb-headed). Adverbial NPNs will be shown to be adverbial NPs; compare I have said it time after time and I have said it many times. Adverbial NPs are not a widespread phenomenon in English or Norwegian, and NPNs may be the only productive adverbial NP type in these languages, covering a larger spectrum of semantic roles than other adverbial NPs. For instance, adverbial NPNs are often manner expressions, and while English does have manner adverbial NPs with way, as in You can't do it that way (compare You can't do it step by step), I know of no such NPs in Norwegian except for NPNs.

The semantic roles of adverbial NPNs are largely unexplored. They can most easily be analysed where an adverbial NPN can be compared to one that is the complement of a preposition (as in I waited (for) hour after hour). The PP has a similar temporal role to that of the adverbial NPN and expresses it with the preposition. These issues are complex and cannot be addressed in full depth here, but building on Kinn (2021a), I will show that adverbial NPNs in Norwegian express at least manner, temporal and local roles.

\subsection{Present claims and objectives}

In this section, I outline the argument of the present paper.

The bare singulars of NPNs have referential properties that are typical of bare singulars in general, involving both types and instances (see Section 3.4). The meaning of a bare singular is a singular nominal type corresponding to one or more instances. The relation in number between types and instances is regular, and there is no need to assume reduplication in NPNs. The nouns in NPNs are identical simply because they are used to invoke the same nominal type.

The meanings of prepositions in NPNs are the same as in some other constructions (but not always the most typical meanings of the prepositions). They have the typical semantic valency of prepositions, relating an external trajector to an internal landmark. That cannot be said of either coordinators or quantifiers. Coordination-like and plurallike properties in NPNs can be explained without recategorization of prepositions.

The PN sequence in NPNs is a PP, inheriting properties from the general PP construction like other PPs with bare singular complements. The preposition is its head, and $\mathrm{N} 2$ is an ordinary complement, designating the landmark of the 
prepositional relation. An NPN is at the core a regular NP, inheriting properties from a general NP construction like other NPs with bare singulars. N1 is the head of the NP, and the PP is its modifier. N1 designates the trajector of the prepositional relation. Adverbial NPNs are exocentric constructions with an additional semantic layer on top of the NP itself, profiling an unspecified relation between an external trajector and a landmark designated by the nominal core of the NPN.

Prepositions involve an asymmetric construal of the relation between a pair of participants: trajector and landmark. In NPNs, there are emergent construals of the organization of nominal participants, giving 'twin' and 'chain' NPNs. In twin NPNs, there is a construed reciprocal relation that strengthens the pairwise organization of participants. In chain NPNs, the prepositional relation is not only asymmetric, but is construed as transitive (see Section 4.2 below). This motivates the emergence of a chain-like organization of instances of the nominal type involved.

The organization of nominal instances in chain NPNs explains their coordination-like properties without the need to assume coordination. It further explains why $\mathrm{N} 1$ and $\mathrm{N} 2$ normally have to be identical in these NPNs (*? day after night). The organization of nominal instances in twin NPNs explains why it is natural that N1 and N2 are identical there too, while non-NPNs like paw in hand are possible.

Chain NPNs have plural-like meanings. This motivates nominal functions of such NPNs. Twin NPNs do not have plural-like meanings and are typically not used in nominal function. Both chain and twin NPNs are found in adverbial functions and are then adverbial NPs. When there is no case marking on N1, adverbial NPNs share a noncompositional property with other adverbial NPs: the absence of an expression specifying the relation between a trajector (external to the NPN) and the landmark meaning of the NPN as a whole (see Section 5). The implicit meaning relation is often one of manner, but also temporal and local relations are found.

This noncompositionality of the top layer of adverbial NPNs is probably the most idiosyncratic property of NPNs. Further, the emergent noun organizations sketched above are construction-specific and not found in NPs with PP modifiers in general. The tendency to lack modifiers is also a typical property of NPNs, although bare singulars tend in general to have few modifiers (Borthen 2003: 128).

Some NPNs are lexicalized. For instance, Norwegian side om side 'side by side' is the only commonly used NPN with the preposition om. The preposition here means 'next to', while it usually means 'about, around'. Another example is Norwegian steg for steg 'step by step', which may have to do with real steps but is typically used about small abstract developments and has come to mean 'gradually, slowly'. Lexicalization is idiosyncratic but not in focus here.

A primary aim of this article is to bring to light the regular and compositional aspects of NPNs. Irregular and noncompositional properties are acknowledged but not a primary focus. Because of space limitations, the integration of adverbial NPNs in larger constructions as well as modifiers in NPNs are dealt with only briefly, but see Kinn (2021a, b) for more detailed accounts of some such issues. 


\section{BARE SINGULARS}

There is solid evidence that bare singulars are sometimes used as arguments even in article languages (Section 3.1), notably in NPNs and related constructions (Section 3.2). Case marking in Icelandic corroborates this view (Section 3.3). A distinction between semantic 'types' and 'instances' provides a needed conceptual basis for an analysis of the structure of NPNs (Section 3.4).

\subsection{Bare singulars in argument functions}

Both English and Norwegian are languages with grammaticalized articles. ${ }^{16} \mathrm{~A}$ restriction against bare singulars in argument functions would therefore be expected to hold for these languages, but it is known that there are exceptions.

Among the constructions with bare singulars that have been discussed for English, apart from NPNs, are the ones illustrated by John is in hospital, the way to use knife and fork, Mary is chair of the department and She is playing piano for the choir (de Swart \& Zwarts 2009: 280). In Stvan (2007), the focus is on location nouns in PPs like in hospital, but her study also documents bare singular location nouns as subjects and objects in English. Goldberg (2013) sees expressions like in hospital as special cases of a general PP construction.

Borthen (2003: 68) finds that 'Norwegian bare singulars can occur in all basic syntactic positions available for nominal phrases in Norwegian, but not "freely" in any of these positions'. She argues that the use of bare singulars is motivated by semantics, and focuses on a set of constructions where they are commonly used. ${ }^{17}$ These are presented in Rosén \& Borthen (2017: 223-224) as (i) the conventional situation type construction (Hun går på skole 'She goes to school'), (ii) the profiled have-predicate construction (Hun hadde rod ytterfrakk 'She had (a) red coat'), (iii) the taxonomic construction (Buss er et naturvennlig kjøretøy '(A/The) bus is a nature-friendly vehicle'), and (iv) the covert infinitival-clause construction (Jeg vil anbefale telt 'I would recommend (having/using) (a) tent'). ${ }^{18}$

There are also certain genre-specific contexts like (7), where bare singulars are more generally acceptable (see Borthen 2003: 17):

(7) Mann bet hund

(www.ba.no)

man bit dog

'Man bit dog'

[16] Norwegian has an indefinite singular article and both a definite (preadjectival) article and definite noun suffixation.

[17] Borthen (2003) uses the term constRuction differently from construction grammars. The details are not essential here.

[18] While one of these examples has an attributive adjective before the noun, there are severe restrictions on this in many cases. Borthen (2003: 128) notes that bare singulars are often less acceptable when they are modified by adjectives. She suggests that this can be explained on the basis that 'modification makes the denotation of a nominal phrase more specific and therefore more situation bound'. This implies that modification may make bare singulars less suited to be used in some kinds of generalization, including the type meaning of NPNs (see Section 3.4 below). 
The example in (7) is a newspaper headline, and the bareness of the nouns is dictated by headline syntax conventions. In body text, one would normally have used indefinite articles, and this use of bare singulars will not concern us further.

Some Norwegian bare singular constructions have English parallels, for example, Hun går på skole and She goes to school. The Norwegian example belongs to Borthen's conventional situation type construction. The bare singular complements of English PPs like to school have been described by Stvan (2007: 171) as 'components of a predicate conveying a stereotypical activity' (see also Goldberg 2013 and de Swart \& Zwarts 2009).

While constructions (i)-(iv) above are certainly central uses of bare singulars in Norwegian, there are others in addition. Rosén \& Borthen (2017: 239) conclude that their data may indicate that 'bare singulars are not licensed through a set of constructions' and that the presence or absence of the indefinite article may constitute 'a phenomenon on a par with the choice between an indefinite [and] a definite article'. The distinction is motivated by, but not fully predictable from, referential differences between the expression types.

\subsection{Bare singulars in NPNs and related uses}

This section presents data that supports the view that the bare singulars of NPNs have argument properties: N2 as (head of) the complement in a PP and N1 as head of an NP.

It is illuminating to note how some NPNs shade off into NPN sequences that are not NPN constructions. The examples in (8) and (9) exhibit the same NPN sequence, but whereas it is one constituent in (8), in (9) the PN sequence is an adverbial constituent separate from the first noun, which is the subject.

(8) så de griper fatt i hverandre og slåss mann mot mann (LBK) so they grab hold in each.other and fight man against man 'So they grab hold of each other and fight man on man.'

(9) I langskipene kjemper mann mot mann (www.duo.uio.no) in the.longships fights man against man

'In the longships, man fights man.'

Further, there are clauses like (10), where the first noun and the PN sequence are overtly separated. ${ }^{19}$

[19] While such expressions as in examples (12) and (13) are not very frequent and certain examples may be slightly 'elevated', they are not genre-limited but should be considered as belonging to the general language system.

The instances of bareness are interdependent; if the subject is changed to en mann 'a man', the prepositional complement must have an indefinite article too, and vice versa. This also changes the referential properties of the nominals. 
(10) og mann kjempet mot mann med bare nevene (books.google.no) and man fought against man with only the.fists

'And man fought man with bare fists.'

Thus, the N1s of certain NPNs may correspond to bare singulars in ordinary argument functions, which weakens any assumption that N1 cannot be the head of a nominal NPN. Further, the PN sequences of NPNs may correspond to separate PPs with bare singular complements, strongly suggesting that they are PPs, as indicated by surface appearances.

NPN-like sequences like the one in (9) are not uncommon. The examples in (11)-(13) illustrate this for three different prepositions.

(11) denne gleden ved å legge maske til maske this the.joy by to lay stitch to stitch 'this joy of adding stitch to stitch (in knitting)'

(12) Midt i denne stillheten [...] satte jeg fot foran fot middle in this the.quiet put I foot in.front.of foot 'In the middle of this quiet, I put foot before foot.'

(13) mens de la stein på stein og reiste seg et hus (LBK) while they laid stone on stone and raised themselves a house 'while they laid stone on stone and built themselves a house'

In each of these examples, the first noun is an object and is followed by a separate PP with the same noun, making the NPN sequence look superficially like an NPN construction. These PPs are valency-bound adverbials; compare Jeg satte fot foran fot 'I put foot before (in front of) foot' and Jeg satte den venstre foten foran den høgre 'I put my left foot in front of the right'.

Further, there are clauses, like those in (14)-(16), where identical bare singulars are used as both subject and object:

(14) Det er en barsk sport, hvor mann møter mann it is a rough sport where man meets man 'It (wrestling) is a rough sport, where man meets man.'

(15) Så lenge slekt følger slekt

so long generation follows generation 'as long as generation follows generation'

(16) Nabo forrådte nabo. Barn forrådte sine foreldre. (LBK) neighbour betrayed neighbour children betrayed their parents 'Neighbour betrayed neighbour. Children betrayed their parents.'

These expressions are clearly distinct from NPNs, of course, but the referential properties of the bare singulars resemble those seen in NPNs and further corroborate Borthen's (2003) claim that bare singulars can be all kinds of arguments in Norwegian. 
These facts about Norwegian bare singulars might appear to set Norwegian far apart from English, and the languages are no doubt partly different. However, uses of bare singulars very similar to the Norwegian ones exist also in English, as (17)-(19) show.

(17) the person who was so laboriously adding stitch to stitch

(www.booksupstairs.com)

(18) Next to it, stone was piled upon stone

(wWw.reads2019.com)

(19) neighbour betrayed neighbour, and friend betrayed friend

(www.times-series.co.uk)

This suggests that English, too, accepts bare singulars in argument positions more readily than is commonly acknowledged. The conditions for such use must be sought in referential properties, as we will see in Section 3.4.

\subsection{Case marking in Icelandic NPNs}

Norwegian and English no longer have case marking of nouns that could shed light on the syntactic functions of bare singulars in NPNs. However, the nouns of Icelandic NPNs are case-marked just like nouns in other constructions. ${ }^{20}$ In nominal NPNs, N1 carries the case of the relevant kind of argument. In (20), dagur 'day' is in the nominative because the NPN is the subject of the clause. (Note also the singular agreement of the verb leið 'passed'.)

$$
\begin{aligned}
& \text { Pannig leið dagur eftir dag } \\
& \text { thus passed.3sg day.NOM after day.ACC } \\
& \text { 'In this way, day after day passed.' }
\end{aligned}
$$

(Icelandic; timarit.is)

This shows that N1 is the head of the nominal NPN.

Adverbial NPs are common in Icelandic. Temporal adverbial NPs are typically in the accusative and manner adverbial NPs in the dative. This is also the case for the N1s in the NPNs in (21) and (22), which are a temporal and a manner adverbial, respectively.
enda
er hér rigning dag
eftir dag
(Icelandic; timarit.is)
because is here rain day.ACC after day.ACC
'because it is raining here day after day'

[20] For similar observations on Polish, see Pskit (2015).

The generalization that bare singulars tend not to be arguments is based on languages with articles. Icelandic is only partly such a language, with a definite article and definiteness inflection, but no grammaticalized indefinite article. It might therefore be objected that evidence from Icelandic is not fully pertinent to the discussion. However, Icelandic and Norwegian are closely related languages, and so are their NPNs. A claim that NPNs have different structures (beyond case marking) in these languages would therefore require solid empirical evidence. 
Nú stóðum við loks augliti til auglitis (Icelandic; www.forlagid.is) now stood we finally face.DAT to face.GEN

'Now we were finally (standing) face to face.'

The case of N1 in adverbial NPNs has a similar function to prepositions taking NPN complements, although case semantics is even less specific than prepositional semantics. The cases in (21)-(22) indicate that the case-marked N1s are the heads of adverbial NPNs.

The case of $\mathrm{N} 2 \mathrm{~s}$ in Icelandic is partly governed by the preposition, partly determined by semantics. In (22), auglitis 'face' is in the genitive governed by til 'to'. In (20) and (21), dag 'day' is in the accusative. The preposition eftir 'after' governs either the accusative or the dative, and specifically the accusative in temporal expressions. This data is strong evidence that $\mathrm{N} 2$ is the complement of the preposition.

Old Norse, the predecessor of both Icelandic and Norwegian, had at least some adverbials like orð eftir orði [word.ACC after word.DAT] 'verbatim' (Heggstad, Hødnebø \& Simensen 1990: s.v. orð) and land af landi [country.ACC off country. DAT] 'from country to country' (s.v. land). ${ }^{21}$ There have probably been several innovations in this field between Old Norse and modern Norwegian. What is clear is that adverbial NPs in general have lost their case marking. This means that the absence of an expression of their external function is the result of case loss, while the internal NP structure is otherwise retained. The Norwegian variation between, for example, adverbial time etter time 'hour after hour' and $i$ time etter time 'for hour after hour' may be regarded as the difference between a lost case marking and a preposition which functions similarly to the lost case.

\subsection{Types and instances}

My analysis of NPNs below builds on the nominal semantics of Cognitive Grammar (Langacker 1987, 1991). Langacker's notions resemble those of Borthen (2003), although the semantic approaches of these two researchers may not be fully compatible in other respects. Since Borthen's primary focus is on bare singulars in Norwegian, her approach is a natural point of departure for an analysis of Norwegian NPNs.

Borthen (2003: 37) finds that bare singulars are poorer antecedent candidates for ordinary personal pronouns than corresponding expressions with an indefinite article. Thus, while en drosje in (23) is a good antecedent of the personal pronoun den, drosje followed by den in (24) sounds a bit odd.

(23) Kari ankom flyplassen i en drosje. Den var grønn. Kari arrived the.airport in a cab it was green 'Kari arrived at the airport in a cab. It was green.'

[21] The latter resembles PNPNs (see footnote 8 above), but with the 'from' and 'to' parts reversed and accusative case rather than a preposition. 
(24) Kari ankom flyplassen i drosje. ?Den var grønn.

Kari arrived the.airport in cab it was green

'Kari arrived at the airport by cab. It was green.'

On the other hand, Borthen (2003) finds that bare singulars are good antecedents of the type anaphor det 'that/it' (a singular form which is neuter regardless of the grammatical gender of the antecedent), see (25).

(25) Jeg har tatt med kniv, i tilfelle vi skulle trenge det. I have taken with $\mathrm{knife}(\mathrm{M})$ in case we should need that.N 'I've brought a knife, in case we should need one.'

These observations and a wealth of other evidence in Borthen (2003) show that bare singulars tend to be used with a focus on the type of individual, while expressions with an indefinite article tend to be used with a focus on the individual itself. Singular nouns on Borthen's analysis thus have a dual character, with a distinction between token discourse referents (typical focus of NPs with an indefinite article) and type discourse referents (typical focus of bare singulars). Borthen's distinction resembles the distinction in Cognitive Grammar (Langacker 1987, 1991) between TYPE and INSTANCE (rather than TOKEN); see also Langacker (2008: 264-272). I will use Langacker's terms in the following. ${ }^{22}$

Let us look more closely at the distinction between types and instances by means of examples and simultaneously show how it can be used to account for the behaviour of bare singulars. The examples in (26) and (27) illustrate a common use of bare singulars in Norwegian.

(26) Oline malte kaffebønner, la duk på bordet

Oline ground coffee.beans laid tablecloth on the.table 'Oline ground coffee beans, put a tablecloth on the table.'
De legger duk
på bordene
they lay tablecloth on the.tables
'They put tablecloths on the tables.'

(www.ifi.no)

In (26), the bare singular $d u k$ is interpreted as involving one single instance: one tablecloth in a specific situation (because there is one table). In (27), it will normally

[22] Closely related to the concept pair 'type' and 'instance' is the pair 'virtual referent' and 'actual referent' (Langacker 1999, 2005). All types are virtual referents. The instances of NPNs are basically actual referents; thus, in The couple walked hand in hand, there are two hands involved in the (real or imaginary) scene. However, the instances may fall under the scope of a virtualizing expression in their context, for example, as in Whenever I see a couple walking hand in hand, I feel happy. In such examples, the instances (hands), too, are virtual. Thus, while the type plane and the instance plane in the figures below could often - in the analysis of a given example - just as well be called a virtual and an actual plane, respectively, there are cases where this is not appropriate. 
be interpreted as involving several tablecloth instances (since there are several tables). However, the bare singular corresponds to a singular type in both examples. The type meaning of the bare singular is a generalization over individual tablecloths with identical roles in several subevents. (The type vs. instance distinction also holds for relational predications, in this case the verbal 'lay'; there is one instance of laying in (26) and several in (27).)

The two readings of $d u k$ are quite similar to what is found for some NPNs. An example is arm i arm 'arm in arm', as in (28) and (29).

Catriona gikk arm i arm med Lucilla (books.google.no) Catriona went arm in arm with Lucilla 'Catriona walked arm in arm with Lucilla.'

(29) Svarte og hvite gikk arm i arm i toget (www.itromso.no) black.PL and white.PL went arm in arm in the.procession

'Blacks and whites walked arm in arm in the procession.'

For (28), the normal reading involves two arm instances, one for each bare singular. For (29), however, it is necessary to assume that there are several pairs of arms, hence more than two arm instances. The tokens of bare singular arm both invoke the 'arm' type, and the preposition $i$ invokes a somewhat vague relational type. In (29), they generalize over several situations with one arm 'in' another.

A problem for studies of NPNs has been the discrepancy in number properties between linguistic levels (see Section 2.2). This problem can be solved if one keeps types and instances apart. NPNs have two singular count nouns, which means that one singular nominal type is invoked twice. At the instance level, an NPN may involve more than two instances, but this discrepancy in number between types and instances is a regular phenomenon for bare singulars.

\section{The internal SEmantic Structures of NPNS}

In this section, the internal conceptual semantics of NPNs is detailed. First, the properties common to all NPNs are presented in Section 4.1. Section 4.2 introduces two kinds of prepositional meanings and corresponding emergent NPN semantics. Sections 4.3-4.6 deal in more detail with the prepositions and NPN semantics, while Section 4.7 discusses prepositions and NPNs where emergent meanings are not as evident.

\subsection{The basic schematic structure of NPNs}

Figure 1 represents the internal semantic structure of the NPN schema. It involves both types and instances. Circles represent singular nominal entities, and the repeated symbol c signifies that one and the same category is involved in each case. In the type plane (TP), a singular nominal type is invoked twice (c $\alpha$ by N1 and $c \beta$ by N2) and therefore represented with two circles. The two are connected by a 


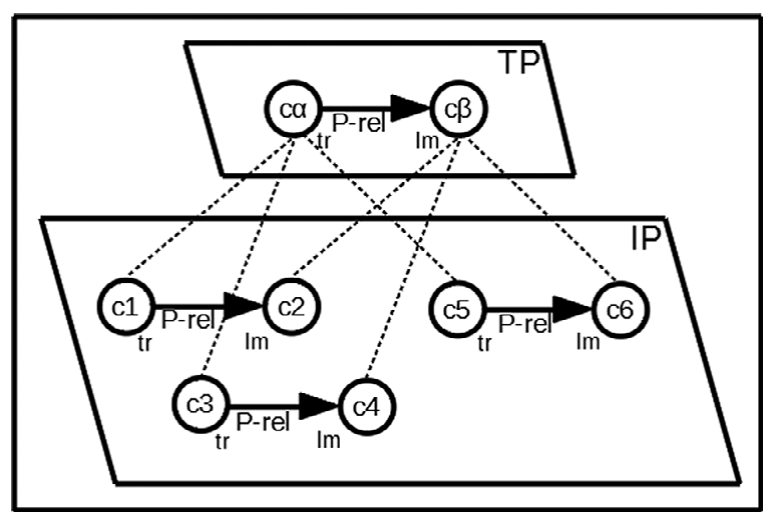

Figure 1

The internal semantics of the NPN schema.

prepositional relation (arrow labelled P-rel). Thus, $c \alpha$ and $\mathrm{c} \beta$ are trajector (tr) and landmark $(1 \mathrm{~m})$, respectively.

The type plane generalizes over an instance plane (IP) with one or more corresponding nominal instances and prepositional relations. Dashed lines indicate correspondences between types and instances. A structure with three instantiations of the relation is shown, hence six nominal instances (c1, c3, and c5 corresponding to $c \alpha$; and $c 2, c 4$, and $c 6$ corresponding to $c \beta$ ). Whether the instance plane has one or more relational instances depends on context (compare The couple(s) walked hand in hand with a singular or plural subject).

In a nominal NPN, the singular trajector $c \alpha$ in the type plane is profiled, which accounts for the fact that subject NPNs trigger singular agreement on verbs even though c $\alpha$ corresponds to several instances in the instance plane.

\subsection{Asymmetry and transitive and reciprocal construals}

Figure 1 shows what is common to all NPNs and is limited to their internal semantic structure. The interplay between the meanings of prepositions and nouns is key to understanding how two semantic variants of NPNs emerge and motivate different syntactic properties. The emergent variants modify the structure in Figure 1 in different ways: One has landmark-trajector identity between relational instances, while the other is construed as having a reciprocal relation between trajectors and landmarks.

Prepositional relations impose an asymmetric construal on the connection between two participants, distinguishing between a trajector and a landmark. Thus, there is always pairwise ordering of participants. The asymmetry is evident in examples such as She threw the ball to the boy, where the ball is the trajector of to and the boy is the landmark. However, asymmetry is often more a matter of construal and may not be evident in the described situation. For instance, in 
examples such as He mixed the sugar with the flour one could often just as well have said He mixed the flour with the sugar. The asymmetry of with is here a matter of construal more than a property of the situation.

Certain prepositions have meanings that are not only asymmetric but also construed as transitive. After is such a preposition: If Kim arrives after Tim and Tim arrives after Jim, then Kim also arrives after Jim. In NPNs, the resulting construal involves nominal instances organized in what I call 'chains'.

Certain other prepositions have meanings whose basic asymmetry may be supplemented by a construed reciprocity of the prepositional relation, if the trajector and the landmark are similar (as they are in NPNs) and tend to be directed towards each other. Against is such a preposition: In an interpretation of Kim fought against $\mathrm{Jim}$, it is natural to assume that Jim fought against Kim, too, although this is not made explicit. There is a construed reciprocity with an implicitly added reversal of trajector and landmark. If the participants are very different or not directed, as in Kim fought against disease, a reciprocal construal is less motivated. Reciprocal construals in NPNs strengthen the pairwise organization of participants to form what I call 'twins'.

The following sections discuss transitive and reciprocal construals in NPNs, as well as NPNs where an emergent semantics is not as evident. The emergent semantics will be shown to explain both the difference between *? day after night and paw in hand and the difference among NPNs in their ability to assume nominal functions.

\subsection{Prepositional relations construed as transitive}

Certain prepositions found in NPNs involve relations between trajector and landmark that are construed as transitive. In Norwegian, this category includes at least etter 'after', for 'by' (lit.: 'for'), and på 'on'. NPNs with these prepositions do not normally have corresponding non-NPNs with different nouns (compare English *? day after night). They can be used in nominal functions.

\subsection{1 $\mathrm{N}$ etter $\mathrm{N}$ ' $N$ after $N$ '}

The preposition etter 'after' typically designates a temporal sequence of participants. An example is dagen etter ulykka 'the day after the accident'. The meaning is the same in $N$ etter $N$ ' $\mathrm{N}$ after $\mathrm{N}$ '. The trajector is an entity that follows the landmark; in NPNs, they correspond to N1 and N2, respectively. The participants may be temporal units or other units that are somehow dealt with one after the other. The NPN in (30) is adverbial, while the one in (31) is nominal (the complement of a preposition).

(30) Men han spilte jo her kveld etter kveld? but he played after.all here evening after evening 'But he played here evening after evening, after all?' 
(31) Hun beveger seg gjennom historie etter historie

she moves herself through story after story

'She moves through story after story.'

\subsection{2 $\mathrm{N}$ for $\mathrm{N}$ ' $N$ by $N$ '}

The closest English equivalent to Norwegian $N$ for $N$ is $N$ by $N .^{23}$ Norwegian for is highly polysemous and very commonly benefactive. However, benefactive meaning does not make any sense in $N$ for $N$. Historically, the basic meaning of for is the local 'in front of', ${ }^{24}$ and a metaphorical extension gives temporal 'before'. Although now peripheral, the local meaning is found for for elsewhere too, for example, in stå for retten 'stand before court'. $N$ for $N$ is mostly used adverbially, as in (32), but nominal use also occurs, like the subject in (33). ${ }^{25}$

(32) Skallet ble plukket av bit for bit

the.shell became picked off piece for piece

'The shell was picked off piece by piece.'

Potte for potte blir fylt med frø av alle slag
pot for pot becomes filled with seeds of all kinds
'Pot after pot is filled with seeds of all kinds.'

\subsection{3 $\mathrm{N}$ på $\mathrm{N}$ ' $N$ upon $N$ '}

The preposition pa '(up)on' is basically local, denoting that a trajector is placed (statically or dynamically) on top of a landmark. An example is bøkene på bordet 'the books on the table'. This is also the basic meaning of $p a ̊$ in $N p a ̊ N$ 'N upon N', but that meaning is quite frequently extended to a more general 'in addition to'. This is congruent with the conceptual metaphor MORE IS UP.

In general, the $N$ på $N$ construction is construed as involving transitivity, but the transitivity of $p a ̊$ itself is not altogether clear. In the local meaning, if A is on top of B and $\mathrm{B}$ is on top of $\mathrm{C}$, then $\mathrm{A}$ is only indirectly on top of $\mathrm{C}$. In the additive meaning, the transitivity is clearer: If $\mathrm{A}$ comes in addition to $\mathrm{B}$ and $\mathrm{B}$ comes in addition to $\mathrm{C}$, then $\mathrm{A}$ also comes in addition to $\mathrm{C}$.

[23] There are also Norwegian $N$ for $N$ sequences of exchange, like $\phi y e$ for $\phi y e$ [eye for eye] 'an eye for an eye', but these are almost completely limited to that one biblical allusion.

[24] According to Norsk Ordbok (Bø et al. 1994: s.v. IX for, A 1 f), Norwegian $N$ for $N$ ' $N$ by N' is based on German $N$ für $N$, and Deutsches Wörterbuch (Grimm \& Grimm 1878: s.v. für, I A 3) states that the meaning of für in $N$ für $N$ is originally 'in front of / before (in a series)'. Thus, $N$ for $N$ is diachronically the converse of $N$ etter $N$ ' $\mathrm{N}$ after $\mathrm{N}$ '. In glosses, I render Norwegian for with English for. In NPNs, it corresponds to English by in adverbials and after in nominals, which I use in idiomatic translations.

[25] Norwegian $N$ for $N$ ' $\mathrm{N}$ by $\mathrm{N}$ ' is more commonly used in nominal function than is English $N$ by $N$, but note that, for example, Day by day went by with an $N$ by $N$ subject is possible. 
Most $N$ på $N$ types are used nominally, like the object in (34).

(34) Sammen slengte vi kasse på kasse over på tralla together threw we crate on crate over on the.trolley 'Together we threw crate upon crate onto the trolley.'

A very frequent adverbial expression is shown in (35).

Og gang på gang blir man skuffet and time on time becomes one disappointed 'And time after time, one is disappointed.'

\subsection{Chain NPN semantics}

As seen, chain NPNs are based on construed transitive prepositional relations among participants, and some prepositions motivate such readings more strongly than others. A chain NPN designates a series or accumulation of units; for example, natt etter natt 'night after night' has the meaning of 'several (consecutive) nights', and kasse på kasse 'crate upon crate' means 'several (accumulated) crates'.

The chain configuration is a property that emerges in the instance plane. In the type plane, there are only two nominal entities (one type invoked twice), in the fundamental pairwise organization of prepositional relations. But as seen in Figure 1, the type plane generalizes over an instance plane with an indefinite number of instances of prepositional relations and nominal participants.

In chain NPNs, the construed transitivity motivates the emergence of a participant configuration where the landmark of one relation instance is understood as token identical to the trajector of the next relation instance. This holds for each pair of relation instances, leading to a chain. The semantic structure of natt etter natt 'night after night' is illustrated in Figure 2 (see Section 4.1 above for explanation of the representation). As in Figure 1, three trajector-landmark pairs are shown in the instance plane, but because of the landmark-trajector identities, the number of different instances is smaller.

The token identity of a landmark in one relation and the trajector of the following relation explains the requirement for the nouns of chain NPNs to be identical (*?day after night). A specific landmark instance (say, n2) corresponds to the landmark type $(\mathrm{n} \beta)$ designated by $\mathrm{N} 2$. The trajector instance following that landmark is token identical to it (is also $\mathrm{n} 2$ ) and corresponds to the trajector type (n $\alpha)$ designated by N1. So $\mathrm{n} 2$ corresponds to both n $\alpha$ and $n \beta-$ and to both N1 and N2. This means that if one landmark is a night (designated by N2), then the next trajector (designated by N1) must also be a night. Therefore, N1 and N2 have to be identical (natt 'night'). If the structure in Figure 2 were to be applied to *?day after night, 'day' trajectors would need to be identical to 'night' landmarks. The identity between nouns is thus explained without any need to resort to the reduplication assumed in some previous research.

Recall that an internal modifier like the of-phrase in layer upon layer of clothes, for example, modifies both nouns. Thus, although the constituent structure is [layer 


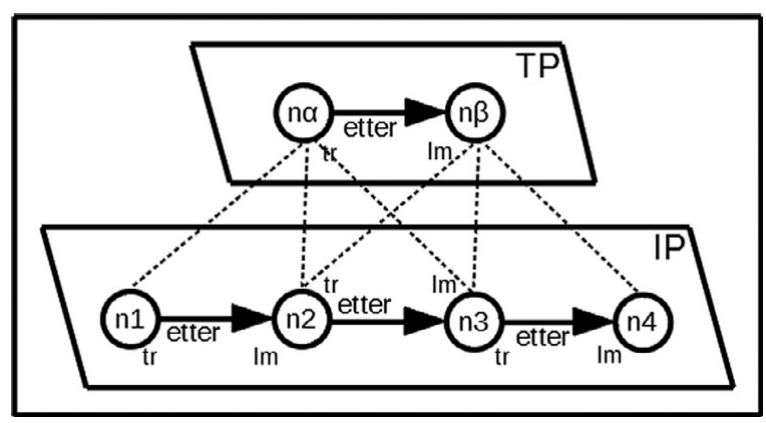

Figure 2

The internal semantics of a chain NPN: natt etter natt 'night after night'.

[upon [layer [of [clothes]]]]], 'of clothes' applies to all semantic instances of 'layer'. On the present analysis, since the instance corresponding to $\mathrm{N} 2$ in one relation instance is token identical to the instance corresponding to N1 in the next relation instance, modification of $\mathrm{N} 2$ automatically means modification of N1. Haïk's (2013) assumption that NPNs involve coordination is therefore unnecessary.

\subsection{Prepositional relations construed as reciprocal}

NPNs with certain prepositions tend to involve reciprocal construals of the relations between nominal participants. These are twin NPNs. In Norwegian, at least two prepositions fall into this category, viz. mot 'against' and til 'to'. NPNs with mot and til may have corresponding non-NPNs with different nouns (compare English paw in hand). They are rarely used in nominal functions (but see Kinn 2021a).

\subsection{1 $\mathrm{N}$ mot $\mathrm{N}$ 'N against $N$ '}

The preposition mot 'against' is historically derived from a noun meaning 'meeting'. It typically involves physical orientation or opposition, as in Han snudde ryggen mot veggen 'He turned his back to (lit.: against) the wall' and Guttene sloss mot jentene 'The boys fought against the girls'. Note the difference between these examples: The former is not construed as reciprocal, while the latter is naturally interpreted so that the girls also fought the boys. The reciprocal construal of fighting is based on the similarity of trajector and landmark (boys and girls) and their ability to be oriented towards each other. The back and the wall are rather different entities and the wall has no clear orientation, so a reciprocal construal is not equally motivated. In NPNs, the trajector and the landmark are always of the same type. In twin NPNs, they are often persons or parts of wholes such as body parts, which are easily understood as directed. This explains the reciprocal construal of $N$ mot $N$ ' $\mathrm{N}$ against $\mathrm{N}$ '. Examples are given in (36) and (37). 
(36) De to armeene sloss mann mot mann

the two the.armies fought man against man

'The two armies fought man on man.'

(37) Vi ligger rygg mot rygg

we lie back against back

(LBK)

'We are lying back to back.'

\subsection{2 $\mathrm{N}$ til N' $N$ to $N$ '}

$N$ til $N$ ' $\mathrm{N}$ to $\mathrm{N}$ ' is not a very frequent kind of NPN. Most cases have to do with people facing each other, as in (38), or people passing information back and forth, as in (39). Similar uses of til are also found outside of NPNs, for instance si noe til noen 'say something to someone'. Til does not in itself motivate reciprocal construals, but since trajector and landmark in NPNs belong to the same category and faces and communicating people tend to be oriented towards each other, reciprocity is usually understood to be involved.

(38) Første intervju ble holdt ansikt til ansikt

first interview became held face to face

'The first interview was done face to face.'

slik at de to kunne samtale, mann til mann so that the two could converse man to man

'so that the two of them could have a conversation, man to man'

\subsection{Twin NPN semantics}

As described, twin NPNs are the result of construed reciprocal prepositional relations among nominal participants, and certain prepositions favour such emergent meanings more than do others. A twin NPN involves one or more pairs of participants. For instance, mann mot mann 'man on (lit.: against) man' is used about two and two men fighting each other, ${ }^{26}$ and ansikt til ansikt 'face to face' is used (when literal) about two and two faces turned towards each other.

The semantic structure of the twin NPN mann mot mann 'man on man' is illustrated in Figure 3, which should be compared to Figures 1-2 (see Section 4.1 above for explanation of the representation). As before, three instances of the prepositional relation are shown in the instance plane. The actual number can be anything from one upwards and can only be determined if information is supplied from the linguistic context. In Jim and Tim fought each other man on man, for example, just two men are involved, but in The regiments fought each other man on man, there are more. In It's tough to fight man on man, the number cannot be determined.

[26] Of course, in the 'real' world, the fighting men may not always appear in tidy pairs, but the semantic construal does involve a pairwise organization. 


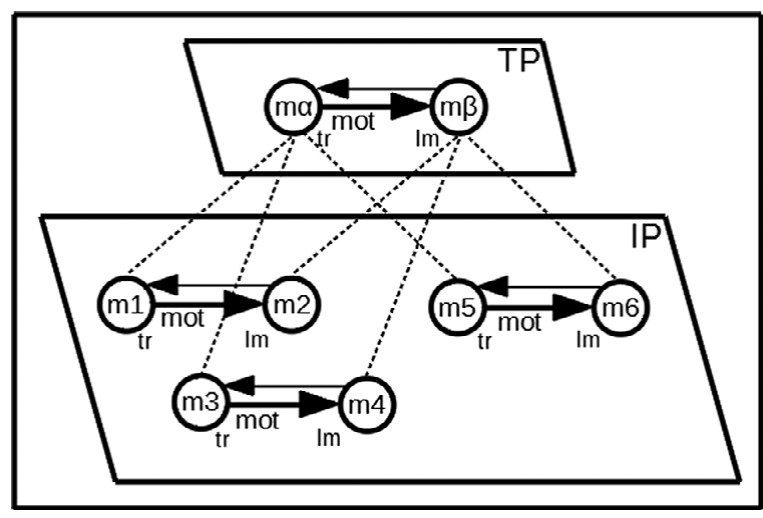

Figure 3

The internal semantics of a twin NPN: mann mot mann 'man on man'.

In twin NPNs, the prepositional relation is construed as reciprocal. This means that there is not only a relationship where the participants corresponding to N1 and $\mathrm{N} 2$ are trajector and landmark, respectively, but there emerges a construal where the same kind of relationship has trajector and landmark reversed. In Figure 3, the emergent 'against'-relation is illustrated with thin arrows. Whereas chain construal emerges only at the instance plane, twin construal is a property of both planes.

In such NPNs, there is no token identity between instances. The set of instances corresponding to the trajector $\mathrm{m} \alpha$ and $\mathrm{N} 1$ does not overlap with that of the landmark $\mathrm{m} \beta$ and N2. Since the nouns correspond to distinct sets of instances, type identity is not necessary. This explains why it is easier to tweak twin NPNs into non-NPN expressions with different nouns, for example, paw in hand: 'Paw' trajectors will not overlap with 'hand' landmarks. Still, the participants need to be fairly similar and able to be directed towards each other in order for the prepositional relation to work both ways; otherwise, no reciprocal construal is motivated. Such expressions are sometimes jocular, as in (40), but far from always, as illustrated by (41).

(40) når han stod ansikt til ... bryst med Trym Halvorsen (sif-bredde.no) when he stood face to ... chest with Trym Halvorsen 'when he was (standing) face to ... chest with Trym Halvorsen' $\begin{array}{lllllll}\text { (41) } \mathrm{Vi} \text { ligger } & \mathrm{i} \text { skje, rygg mot mage } & \text { (www.indre.no) } \\ \text { we lie } & \text { in spoon back against belly }\end{array}$

'We are lying in spoon position, back to belly.'

\subsection{NPNs without clear construals of transitivity or reciprocity}

While many NPNs are clear cases of chain or twin NPNs, there are also less clear cases. NPNs with certain prepositions are not strongly tied to either transitive or reciprocal construals. This pertains, for instance, to NPNs with $i$ 'in' and ved 'by, 
next to'. Such expressions still fit the general NPN schema of Figure 1 above. They are generally more similar to twin NPNs because they lack the very distinctive participant organization of chain NPNs in the instance plane.

\subsection{1 $\mathrm{N}$ i N ' $N$ in $N$ '}

When the preposition $i$ 'in' is used in NPNs, it does not have its typical containment meaning, but designates a relation of closeness and contact between a trajector and a landmark (also observed for $i$ in certain other expressions, e.g. De holdt hverandre $i$ hånda 'They held each other by (lit.: in) the hand'). The participants may for instance be body parts, as in (42), or events in immediate sequence, as in (43).

(42) Gutter og jenter slentret hånd $\mathrm{i}$ hånd boys and girls sauntered hand in hand 'Boys and girls were sauntering hand in hand.'

(43) Bilen gikk kast i kast ned skråningen the.car went throw in throw down the.slope 'The car tumbled topsy-turvy down the slope.'

(42) is most naturally construed as involving reciprocity because the hands are oriented towards each other, like in twin NPNs. (43) is rather idiosyncratic, but not unique (there are similar expressions like hopp i hopp 'jump after (lit.: in) jump'). The 'throws' are connected, but not oriented towards each other like twins. Rather, they are oriented in the same direction. Therefore, such NPNs come to be construed as involving a chain of instances.

\subsection{2 $\mathrm{N} \operatorname{ved} \mathrm{N}$ ' $N($ next) to $N$ '}

The preposition ved 'by, next to' typically has a local meaning. The trajector and the landmark are close, in various ways understood as having their sides next to each other. Two examples of NPNs are given in (44) and (45).

(44) Jødene sloss skulder ved skulder med muslimene (LBK) the.Jews fought shoulder by shoulder with the.Muslims 'The Jews fought shoulder to shoulder (together) with the Muslims.'

(45) hotellene som lå palmehage ved palmehage langs the.hotels that lay palm.garden by palm.garden along strandpromenaden the.beach.promenade 'the hotels that lay palm garden next to palm garden along the beach promenade'

Example (44) has a reciprocal twin construal, of pairs of individuals fighting with their shoulders next to each other, supporting each other. The example in (45) is not altogether clear. But it seems that the palm gardens are construed as forming a chain, 
because langs strandpromenaden 'along the beach promenade' indicates a stretch that would accommodate a number of gardens in a line along the promenade.

\section{The EXternal CONNECTIONS OF NPNS}

Some NPNs are normally only used as adverbials, while others are also used in nominal function. This can be explained on the basis of twin and chain semantics (Section 5.1). Adverbial function involves an extra semantic layer (Section 5.2). Adverbial NPNs have variable semantic roles, at least manner, time, and distance (Section 5.3).

\subsection{Nominal vs. adverbial function}

All kinds of NPNs appear to be able to have adverbial functions, but the range of NPNs that function nominally is restricted. In English, this is mostly NPNs with after and (up)on, and in Norwegian, primarily those with etter 'after', for 'for', and på '(up)on' (see Section 4.3). All of these are chain NPNs. Twin NPNs are only rarely used in nominal functions (see Section 4.5 above and Kinn 2021a).

A chain NPN involves a series of instances, similar to a plural noun meaning. The plural-like meaning is what makes it a viable candidate for nominal syntactic functions. The strengthening from a minimum of two instances to 'several' and 'many' is found also in certain ordinary plurals, for example, English Years have gone by. The main departure from an ordinary plural is the sequential ordering of instances. Another is that, as the head of the NPN, N1 in subjects triggers singular verb agreement, at least in English and Icelandic.

A twin NPN involves one or more pairs of instances that are construed as reciprocally related. The twins in a pair are oriented towards each other and away from other pairs. The participants are construed more in terms of that special configuration than a plurality. This makes twin NPNs less viable for nominal function, and better suited as manner adverbials. Thus, the syntactic difference between chain and twin NPNs is explained by their semantics.

With nominal functions being somewhat peripheral in the grammar of NPNs, one might speculate that adverbial functions are historically primary for all NPN types in Germanic languages, including chaining ones. Their origin would then be casemarked adverbial NPs, and nominal function would be an innovation. This hypothesis needs to be explored on the basis of historical language data. At present, I have no solid basis for substantiating or disproving it.

Chain NPNs with etter, for, and på are the most productive NPN types in Norwegian (see Kinn 2021a), and it might be that productivity and extension from adverbial to nominal use are related. It should be observed, however, that lowfrequency chain NPNs like Norwegian $N$ bak $N$ and the English equivalent $N$ behind $N$ do sometimes occur in nominal functions, as in (46) and (47): 
REGULAR AND COMPOSITIONAL ASPECTS OF NPN CONSTRUCTIONS

et landskap [...] der blåne bak blåne dannet en mektig a landscape where blue.shape behind blue.shape formed a mighty portal portal

(LBK)

'a landscape where mountain behind mountain formed a mighty portal'27

Mountain behind mountain is lost in distant perspective (books.google.no) ${ }^{28}$

\subsection{The additional layer of adverbial NPNs and internal vs. external modifiers}

Nominal NPNs are connected to embedding constructions through being participants of relations, mainly expressed by verbs (NPNs as subjects and objects) and prepositions (NPNs as complements). In such cases, the NPN profiles the meaning of N1, as illustrated in Figure 4 with the thicker line around $c \alpha$. For simplicity, the distinction between types and instances is omitted here.

Adverbial NPNs have the same overt internal nominal structure, but they have an additional semantic layer that turns them into modifiers in embedding constructions - mainly adverbials. In Norwegian and English, there is no overt expression of how the NPNs connect to other syntactic constituents. In this, they are like other adverbial NPs.

Such adverbial NPNs are semantically argument-taking constituents comparable to, for example, prepositional phrases. This is seen in a comparison of Jeg venta $i$ time etter time 'I waited for hour after hour' and Jeg venta time etter time 'I waited hour after hour'. The latter sentence may be said to involve the same temporal relation between waiting and duration as is designated by $i$ 'in' (English for) in the former, but it is not expressed by any morpheme. The meaning of both expressions is illustrated in Figure 5. The basic nominal NPN meaning from Figure 4 has here become the landmark of a relation (called 'rel', to cover both the implicit relation of the adverbial NPN and the prepositional relation expressed by $i$ 'in'). The trajector square signifies whatever is the external participant (the waiting in the sentences above). The profile is the higher relation. This means that if it is left implicit, no constituent of the adverbial NPN has the same profile as the NPN. Adverbial NPNs

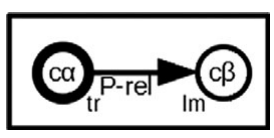

Figure 4

Profiling in a nominal NPN.

[27] The noun blåne is used about far-away shapes (often mountains) appearing blue against the horizon.

[28] The example is from a 19th-century English book in spite of the Norwegian web address. 


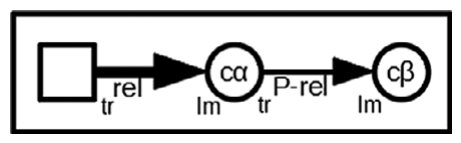

Figure 5

NPN meaning as the landmark of a higher relation (prepositional or implicit).

are therefore exocentric constructions - a noncompositional, but not entirely irregular feature.

I consider the semantic integration of an adverbial NPN in an embedding construction to be noncompositional because of the lack of an expression of its semantic role (in non-case languages). This does not preclude, however, the possibility of analyses that attempt to determine the semantic role on the basis of the overtly expressed meanings of (the words in) the NPN, the head of the embedding construction (usually a verb), and other constituents of the embedding construction. After all, language users need to do something similar in order to be able to produce and understand utterances involving adverbial NPNs, and it is what I do in Section 5.3 below, on an intuitive basis as a native speaker of Norwegian.

It may reasonably be questioned whether twin NPNs, which normally do not have nominal function, can meaningfully be considered to involve NPs. This should be seen in the light of case marking. As shown, Icelandic adverbial NPNs have a case marking on $\mathrm{N} 1$ that goes some way towards expressing the external relation that is left implicit in adverbial NPNs in Norwegian and English - 'some way' because the accusative and dative cases in Icelandic are even more polysemous and multifunctional than prepositions. Norwegian adverbial NPNs are almost exactly like Icelandic ones - except for the case marking. It would take strong empirical evidence to show that adverbial NPNs in these closely related languages have markedly different structures. They all have the internal structures of NPs.

Two common kinds of modifiers in NPNs were illustrated in examples (3) and (4) in the introduction, and the difference can now be explained. They are hierarchically integrated in different ways, as shown in Figures 6 and 7.29

Internal modifiers as in Figure 6 were discussed in Section 4.4. External modifiers are constituents of the exocentric adverbial NPN construction. While the nominal part of the NPN is a complement of the implicit adverbial relation, such a modifier takes the adverbial relation as its trajector. In the case of a PP modifier, the landmark is the complement meaning; in Figure 7, med connects the manner relation of 'face to face' to the companion 'the enemy'.

[29] Note that these tree structures are constructional representations and not simply syntactic ones, since 'head', 'complement' (and, more specifically, 'object'), and 'modifier' are semantically defined notions in Cognitive Grammar (Langacker 1987: 309). 


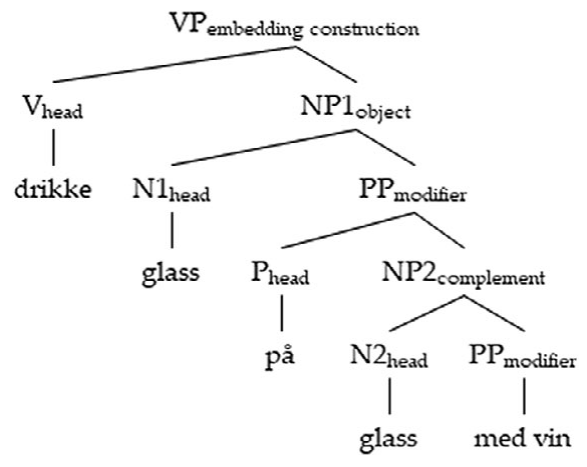

Figure 6

Constructional representation of a nominal (object) NPN with an internal modifier: 'drink glass upon glass of wine'.

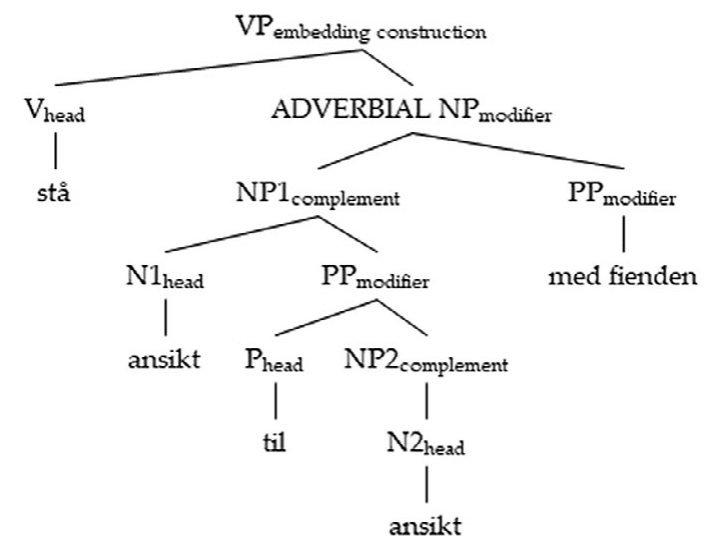

Figure 7

Constructional representation of an adverbial NPN with an external modifier: 'stand face to face with the enemy'.

\subsection{The semantic roles of adverbial NPNs}

The distinction between twins and chains proves to be important not only for adverbial vs. nominal function, but also with respect to the variable semantic roles of adverbial NPNs. Twin NPNs in Norwegian are normally manner adverbials, as possible answers to the question 'how?'. Such expressions tend to involve nouns for body parts or parts of other kinds of objects, the wholes typically being the subject referents. Examples are given in (48)-(50). 
(48) De gikk arm i arm nedover mot sjøen (LBK) they went arm in arm downward against the.sea 'They walked arm in arm down towards the sea.'

(49) og flyene støtte sammen front mot front (LBK) and the.planes hit together front against front 'And the planes collided front to front.'

(50) Da kan jeg stå ansikt til ansikt med publikum then can I stand face to face with audience 'Then I can stand face to face with the audience.'

The semantic roles of adverbial chain NPNs are more variable. $N p a ̊ N$ 'N upon N', as in (51), exhibits the least variation; all adverbials seem to be expressions of manner, except the temporal gang på gang 'time after time' (see below).

(51) alle hagene var anlagt lag på lag i terrasser all the.gardens were laid.out layer on layer in terraces 'All the gardens were laid out layer upon layer in terraces.'

The manner role is frequent for $N$ etter $N$ ' $\mathrm{N}$ after $\mathrm{N}$ ' and $N$ for $N$ ' $\mathrm{N}$ by $\mathrm{N}$ ', too; (52)-(53) illustrate this.

(52) Knapp etter knapp åpnet han frakken (LBK) button after button opened he the.coat 'Button after button, he opened his coat.'

$$
\begin{aligned}
& \text { etter at hun ladet magasinet patron for patron } \\
& \text { after that she loaded the.clip cartridge for cartridge } \\
& \text { 'after she loaded the clip cartridge by cartridge' }
\end{aligned}
$$

$N$ for $N$ ' $\mathrm{N}$ by $\mathrm{N}$ ' and especially $N$ etter $N$ ' $\mathrm{N}$ after $\mathrm{N}$ ' with nouns denoting time units can be temporal adverbials (of duration, location, or frequency, possible answers to the questions 'for how long?', 'when?', and 'how often?'), rather than manner adverbials. This is exemplified in (54) and (56). The highly frequent gang på gang is illustrated in (55).

(54) Han ble liggende i sengen uke etter uke he became lying in the.bed week after week 'He remained in bed week after week.'

(55) Han gjentok det gang på gang he repeated it time on time 'He repeated it time after time.'

(56) Konsentrasjonen av klimagasser $\varnothing \mathrm{ker}$ år for år the.concentration of climate.gases increases year for year 'The concentration of greenhouse gases increases year by year.' 
Uke etter uke in (54) is an expression of duration; it describes the length of time that 'he' spent in bed. Gang på gang in (55) is an expression of frequency. With $N$ for $N$ ' $\mathrm{N}$ by N', the difference from manner is not always obvious. In (56), år for år may be interpreted as describing the manner of distribution of increase over years, but another reasonable interpretation is that it describes the temporal location of increase in each successive year.

Further, $N$ etter $N$ adverbials with nouns denoting length units, as in (57), typically refer to distances. Here, kilometer etter kilometer does not describe the manner of running, but rather the distance (a possible answer to the question 'how far?').

Han løp kilometer etter kilometer langs hovedveien he ran kilometre after kilometre along the.main.road

'He ran kilometre after kilometre along the main road.'

When the instances of the NPN meaning are co-extensive with the meaning of some other constituent of the clause (especially the subject), manner adverbials may blend into secondary predicates (essive meaning). This goes for both twin and chain NPNs. An example with twin $N$ mot $N$ ' $\mathrm{N}$ against $\mathrm{N}$ ' is given in (58).

Vi gjør opp mann mot mann
we do up man against man
'We settle it man to man.'

This NPN may be taken to describe the manner of settlement. Another imaginable interpretation is that it describes the subject referents rather than their action.

While the latter alternative is not obvious in Norwegian, it is clearer in Icelandic. For instance, in the NPN maður gegn manni in (59), N1 maður is not in the dative case typical of manner adverbial NPs, but in the nominative case of a subject predicate. (The dative on $\mathrm{N} 2$ manni is governed by gegn.)

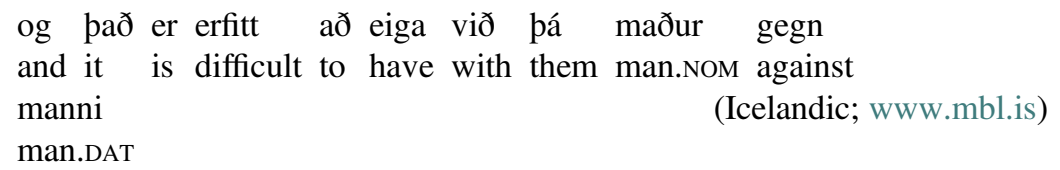

'And it is difficult to deal with them man to man.'

As has become clear, NPNs assume various functions in embedding constructions. Their internal semantics partly determines their possible external connections. Only chain NPNs normally assume nominal functions. Adverbial NPNs, like other adverbial NPs, have an implicit semantic role in the embedding construction. In Norwegian, most adverbial NPNs express manner, but some pertain to duration, frequency, temporal location, or distance, and some resemble secondary predicates. The construals involved in the external semantics of adverbial NPNs deserve more detailed exploration in future research. 
NPNs are involved in a number of complex phenomena that have not been explored here, for instance aspectuality. One issue that has occupied some researchers is plurality of events (e.g. Beck \& von Stechow 2005, 2007). Especially the use of chain NPNs tends to indicate multiple events. In (55) above, the use of gang på gang 'time after time' expresses directly an iteration of the whole event. In (53) above, the use of patron for patron 'cartridge by cartridge' brings to the fore the subevents of the clip loading, which would otherwise have been construed holistically. Much remains to be explored in this field.

\section{Conclusion}

Previous research has sometimes seen NPNs as idiosyncratic and resisting analyses as more 'well-behaved' regular and compositional constructions. My objective has been to show that NPNs are less idiosyncratic than generally recognized. All NPNs involve an NP headed by N1. The PN sequence is a modifying PP with N2 as (head of) its complement. Categorizing NPNs as NPs with PP modifiers implies that they inherit regular properties of more general NP and PP constructions.

As NPs, NPNs are expected to assume nominal functions. The fact that most of them are adverbials is their clearest noncompositional characteristic. An adverbial NPN has the form of an NP but involves an additional semantic layer that makes it an exocentric construction with modifier function in the embedding construction.

It has been shown in some detail how bare singular count nouns do sometimes function as arguments in article languages. This is not a novel move but one that was made forcefully for Norwegian already by Borthen (2003). Others have done similar work for other languages, like Stvan (2007) on English. Bare singulars can be effectively analysed in a construal-based semantics employing a distinction between types and instances. The bare singulars of NPNs share properties with bare singulars in general.

The prepositions involved in NPNs are clearly 'real' prepositions, designating a relation between a trajector and a landmark designated by $\mathrm{N} 1$ and N2, respectively. Most prepositions favour one of two kinds of relations between participants: reciprocal or transitive. In turn, this leads to emergent construals where the nominal instances are organized as either twins or chains.

Both chain and twin NPNs assume adverbial functions, and twin NPNs are only rarely nominal. The chain organization of instances in chain NPNs is what facilitates nominal function for such NPNs. The deeper cause is that chain organization resembles pluralization while twin organization does not. The semantic difference between twin and chain NPNs thus explains a fundamental syntactic dichotomy among NPNs. Chaining further explains why the nouns of chain NPNs must be identical, while the participant organization in twin NPNs makes NPN-like expressions with different nouns more acceptable. The present analysis explains the plural-like and coordination-like properties of chain NPNs without resorting to 
assumptions that the preposition is a quantifier or coordinator, or that $\mathrm{N} 1$ is reduplicated from $\mathrm{N} 2$.

Nominal NPNs receive their semantic roles from the heads of embedding constructions, usually a verb or preposition. The semantic roles of adverbial NPNs, on the other hand, are implicit in non-case languages, as they are with all adverbial NPs. In a case language like Icelandic, the cases indicate such roles vaguely. Adverbial twin NPNs appear to be restricted to manner expressions. Adverbial chain NPNs are often manner adverbials, too, but locative and especially temporal adverbials are also common. The semantic role of adverbial NPNs involves an interplay between the meaning of (the words of) the NPN and the meanings of the head and other constituents of the embedding construction which should be studied more closely in future research.

\section{REFERENCES}

Beck, Sigrid. 2021. Multiple events and 'N preposition N'. Ms., University of Tübingen. [To appear in Patricia Cabredo Hofherr \& Jenny Doetjes (eds.), The Oxford handbook of grammatical number. Oxford: Oxford University Press.]

Beck, Sigrid \& Arnim von Stechow. 2005. Dog after dog revisited. In Christian Evert \& Cornelia Endriss (eds.), Proceedings of the Sinn und Bedeutung 10 (ZAS Papers in Linguistics 44), 43-54.

Beck, Sigrid \& Arnim von Stechow. 2007. Pluractional adverbials. Journal of Semantics 24, 215-254.

B $\varnothing$, Reidar, Arnbjørg Hageberg, Laurits Killingbergtrø, Sigurd Nordlie \& Gunnar Pedersen (eds.). 1994. Norsk ordbok: ordbok over det norske folkemålet og det nynorske skriftmålet, vol. 3: Flusker-gigla [Norwegian dictionary: Dictionary of Norwegian dialects and Norwegian Nynorsk, vol. 3: Fluskergigla]. Oslo: Det Norske Samlaget.

Boberg, Per. 2009. Word by word, phrase by phrase, sentence by sentence: A corpus-based study of the $N_{l}$ by $N_{l}$ construction. Master's thesis, Växjö University.

Borthen, Kaja. 2003. Norwegian bare singulars. Ph.D. dissertation, Norwegian University of Science and Technology.

Culicover, Peter W. 1999. Syntactic nuts: Hard cases, syntactic theory, and language acquisition. Oxford: Oxford University Press.

de Swart, Henriëtte \& Joost Zwarts. 2009. Less form - more meaning: Why bare singular nouns are special. Lingua 119, 280-295.

Faarlund, Jan Terje, Svein Lie \& Kjell Ivar Vannebo. 1997. Norsk referansegrammatikk [Norwegian reference grammar]. Oslo: Universitetsforlaget.

Goldberg, Adele. 2013. Constructionist approaches. In Hoffmann \& Trousdale (eds.), 15-31.

Grimm, Jacob \& Wilhelm Grimm. 1878. Deutsches Wörterbuch, vol. 4.1.2: Forschel-Gefolgsmann. Leipzig: Hirzel.

Haïk, Isabelle. 2013. Symmetric structures. Corela 11. http://corela.revues.org/2875 (accessed 11 January 2021).

Haïk, Isabelle. 2018. Condition B in NPN. McGill Working Papers in Linguistics 25, 146-155.

Heggstad, Leiv, Finn Hødnebø \& Erik Simensen. 1990. Norrøn ordbok [Old Norse dictionary], 4th edn. Oslo: Det Norske Samlaget.

Hoffmann, Thomas \& Graeme Trousdale. 2013. The Oxford handbook of Construction Grammar. Oxford: Oxford University Press.

Jackendoff, Ray. 2008. 'Construction after construction' and its theoretical challenges. Language 84, $8-28$.

Kinn, Torodd. 2001. Pseudopartitives in Norwegian. Ph.D. dissertation, University of Bergen.

Kinn, Torodd. 2021a. “... men ble stående ansikt til ansikt i time etter time”. Norske NPNkonstruksjonar ['but remained standing face to face for hour after hour': Norwegian NPN constructions]. Ms., University of Bergen. [To appear in Maal og Minne.]

Kinn, Torodd. 2021b. Ar etter år, skritt for skritt og lag på lag: tre NPN-konstruksjonar ['Year after year', 'step by step', and 'layer upon layer': Three NPN constructions]. Ms., University of Bergen. [To appear in Randi Neteland \& Torodd Kinn (eds.), Han Johan og dei. Veneskrift til Johan Myking 


\section{TORODD KINN}

ved syttiarssleitet [Johan and friends: Festschrift for Johan Myking on the occasion of his 70th birthday].]

Knudsen, Rune Lain \& Ruth Vatvedt Fjeld. 2013. LBK 2013: A balanced, annotated national corpus for Norwegian Bokmål. Proceedings of the Workshop on Lexical Semantic Resources for NLP at NODALIDA 2013; May 22-24, 2013; Oslo, Norway (NEALT Proceedings Series 19), 12-20. https://ep.liu.se/konferensartikel.aspx?series=ecp\&issue=88\&Article_No=3 (accessed 11 January 2021).

König, Ekkehard \& Claire Moyse-Faurie. 2009. Spatial reciprocity: Between grammar and lexis. In Johannes Helmbrecht, Yoko Nishina, Yong-Min Shin, Stavros Skopeteas \& Elisabeth Verhoeven (eds.), Form and function in language research: Papers in honour of Christian Lehmann, 57-68. Berlin: De Gruyter Mouton.

Langacker, Ronald W. 1987. Foundations of Cognitive Grammar, vol. 1: Theoretical prerequisites. Stanford, CA: Stanford University Press.

Langacker, Ronald W. 1991. Foundations of Cognitive Grammar, vol. 2: Descriptive application. Stanford, CA: Stanford University Press.

Langacker, Ronald W. 1999. Virtual reality. Studies in the Linguistic Sciences 29, 77-103.

Langacker, Ronald W. 2005. Dynamicity, fictivity, and scanning: The imaginative basis of logic and linguistic meaning. In Diane Pecher \& Rolf A. Zwaan (eds.), Grounding cognition: The role of perception and action in memory, language and thinking, 164-197. Cambridge: Cambridge University Press.

Langacker, Ronald W. 2008. Cognitive Grammar. Oxford: Oxford University Press.

Lindquist, Hans \& Magnus Levin. 2003. The grammatical properties of recurrent phrases with body-part nouns: The $N_{l}$ to $N_{l}$ pattern. In Ute Römer \& Rainer Schulze (eds.), Exploring the lexis-grammar interface, 171-188. Amsterdam: John Benjamins.

Longobardi, Giuseppe. 1994. Reference and proper names: A theory of N-movement in syntax and logical form. Linguistic Inquiry 25, 609-665.

Magri, Véronique, Gérald Purnelle \& Dominique Legallois. 2016. Mot à mot, brin par brin: les suites [Nom préposition Nom] comme indices de littérarité ? JADT2016, Journées internationales d'Analyse statistique des Données Textuelles, 7-10juin 2016 Nice (France). https://hal.archives-ouvertes.fr/ hal-01371226/document (accessed 11 January 2021).

Matsuyama, Tetsuya. 2004. The $N$ after $N$ construction: A constructional idiom. English Linguistics 21, $55-84$.

Müller, Gereon. 2011. Regeln oder Konstruktionen? Von verblosen Direktiven zur sequenziellen Nominalreduplikation. In Stefan Engelberg, Anke Holler \& Kristel Proost (eds.), Sprachliches Wissen zwischen Lexikon und Grammatik, 211-249. Berlin: de Gruyter.

Pi, Chia-Yi Tony. 1995. The structure of English iteratives. In Päivi Koskinen (ed.), Proceedings of the 1995 Annual Conference of the Canadian Linguistic Association, Toronto Working Papers in Linguistics 14, 434-445.

Poss [Poß], Michaela. 2007. Structural versus constructional semantics: The case of Dutch NPN. Leiden Working Papers in Linguistics 4, 21-39.

Poß, Michaela. 2010. Under construction: Cognitive and computational aspects of extended lexical units. Utrecht: LOT Publications.

Postma, Gertjan. 1995. Zero semantics: A study of the syntactic conception of quantificational meaning. $\mathrm{Ph} . \mathrm{D}$. dissertation, Leiden University.

Pskit, Wiktor. 2012. The English NPN forms: Words or constructions? In Waldemar Skrzypczak, Tomasz Fojt \& Sławomir Wacewicz (eds.), Exploring language through contrast, 126-144. Newcastle upon Tyne: Cambridge Scholars.

Pskit, Wiktor. 2015. The categorial status and internal structure of NPN forms in English and Polish. In Anna Bondaruk \& Anna Prażmowska (eds.), Within language, beyond theories, vol. 1: Studies in theoretical linguistics, 27-42. Newcastle upon Tyne: Cambridge Scholars.

Pskit, Wiktor. 2017. Linguistic and philosophical approaches to NPN structures. In Wiktor Pskit (ed.), Topics in syntax and semantics: Linguistic and philosophical perspectives, 93-110. Łódź: Wydawnictwo Uniwersytetu Lódzkiego.

Roch, Claudia, Katja Keßelmeier \& Antje Müller. 2010. Productivity of NPN sequences in German, English, French, and Spanish. In Manfred Pinkal, Ines Rehbein, Sabine Schulte im Walde \& Angelika Storrer (eds.), Semantic approaches in natural language processing. Proceedings of the Conference on Natural Language Processing 2010, 157-161. Saarbrücken: Universaar. 


\section{REGULAR AND COMPOSITIONAL ASPECTS OF NPN CONSTRUCTIONS}

Rosén, Victoria \& Kaja Borthen. 2017. Norwegian bare singulars revisited. In Victoria Rosén \& Koenraad De Smedt (eds.), The very model of a modern linguist: In honor of Helge Dyvik (Bergen Language and Linguistics Studies (BeLLS) 8), 220-240. https://bells.uib.no/index.php/bells/article/ view/1330/1216 (accessed 11 January 2021).

Saurenbach, Holger. 2008. Secondary-predicate constructions in English. Saarbrücken: VDM Verlag. Stvan, Laurel Smith. 2007. The functional range of bare singular count nouns in English. In Elisabeth Stark, Elisabeth Leiss \& Werner Abraham (eds.), Nominal determination: Typology, context constraints, and historical emergence, 171-187. Amsterdam: John Benjamins.

Travis, Lisa deMena. 2001. The syntax of reduplication. In Minjoo Kim \& Uri Strauss (eds.), Proceedings of the Thirty-first North East Linguistic Society (NELS 31), 455-469. Amherst, MA: GLSA.

Travis, Lisa deMena. 2003. Reduplication feeding syntactic movement. In Sophie Burelle \& Stanca Somesfalean (eds.), Proceedings of the 2003 Canadian Linguistic Association Annual Conference, 236-247. Montreal: Université du Québec à Montréal.

Ziem, Alexander. 2018. Tag für Tag Arbeit über Arbeit. Konstruktionsgrammatische Zugänge zu Reduplikationsstrukturen im Deutschen. In Kathrin Steyer (ed.), Sprachliche Verfestigung: Wortverbindungen, Muster, Phrasem-Konstruktionen, 25-48. Tübingen: Narr Francke Attempto.

Zwarts, Joost. 2013. From N to N: The anatomy of a construction. Linguistics and Philosophy 36, 65-90.

Author's address: Department of Linguistic, Literary and Aesthetic Studies, University of Bergen, P.O. Box 7800, NO-5020 Bergen, Norway torodd.kinn@uib.no 